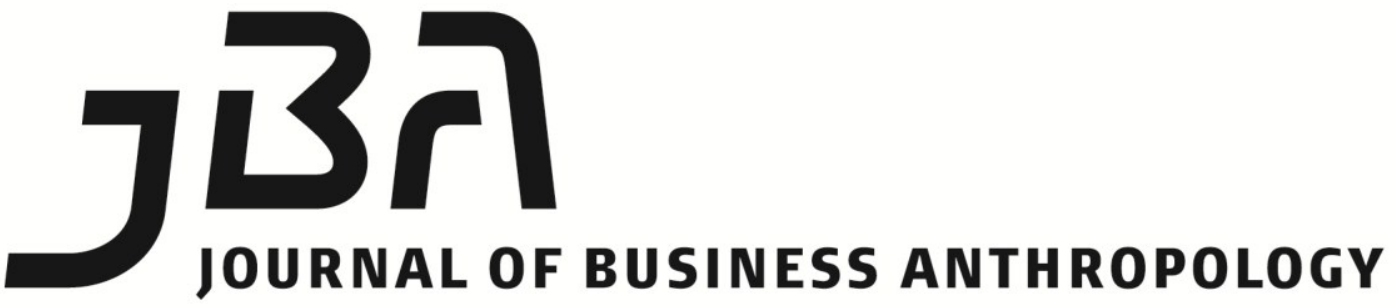

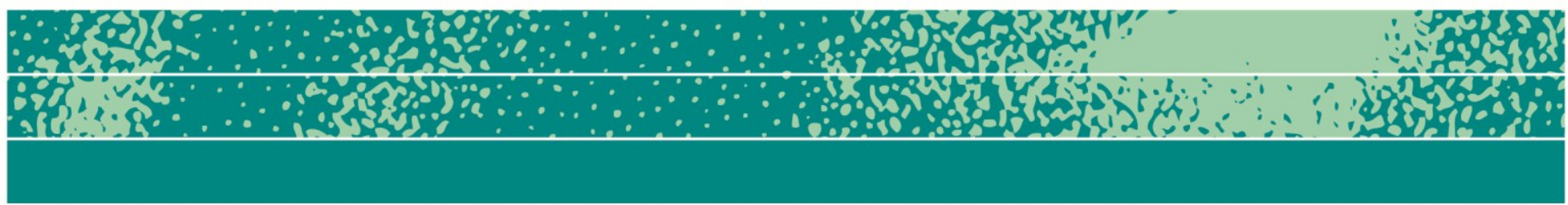

\section{Organization Theory Meets Anthropology: A Story of an Encounter}

\author{
Barbara Czarniawska
}

\begin{abstract}
This text briefly depicts the history of an encounter between anthropology and organization theory in the Anglo-Saxon literature in the period 1990-2010 as seen by an organization scholar. In focus are some stable characteristics and some changes in this relationship, against the background of wider developments in societies and in social sciences. The article ends with suggestions concerning future possibilities of combining the insights of the two fields in a fruitful and interesting way.
\end{abstract}

Page 1 of 23

\section{Keywords}

Anthropology, organization theory, social science 


\section{Introduction}

This is a story of two decades of interaction between organization studies and anthropology, told by an organization scholar. Like all stories, it is one-sided. Much as this interaction has enriched organization theory, it would be incorrect to claim that organization scholars have become fullfledged anthropologists, the recent fashion for "organizational ethnography" notwithstanding. Organization researchers have looked into the field of anthropology and borrowed devices that seemed useful; translated concepts for their own use; changed and adapted, not always faithfully. It can be said that we organization scholars have poached within anthropology's terrain. In our defence stands Michel de Certeau, who said that "readers are travellers; they move across lands belonging to someone else, like nomads poaching their way across fields they did not write, despoiling the wealth of Egypt to enjoy it themselves" (de Certeau, 1984: 174). Thus the following account, no doubt faulty and partial itself, tries to render the process and the results of an encounter between two academic disciplines from the perspective of one of them. A corresponding account from the other side would be a valuable complement to this picture. 1

The story starts with a short excursion back into the 1970s, to create a background for its actual beginning: the 1990s. It was in the early 1990s that organization scholars "discovered" anthropology. It was not for the first time (see, for example, Jaques, 1951; Rice, 1958; Turner, 1971), but it was then that the geopolitical climate made the encounter truly noticeable. Under an umbrella of "organizational culture", at least two distinct schools of thought began to form: one that saw a new management tool in organizational culture, and an opportunity for organization studies to turn to humanities and symbolic analysis. Both have accomplished their goals, although the gap between them has grown bigger and bigger. The first group based its work on traditional anthropology; the second joined forces with anthropology's internal revolution.

Twenty years later, organization culture as a tool of management has given way to storytelling, while organizational symbolists have been taken to task by supporters of studies of science and technology (SST) for neglecting objects, bodies and machines. It can be somewhat surprising, therefore, that ethnography as a method of field study has now spread within both groups. Marketing and information technology people use ethnographies for practical purposes; researchers write ethnographies of

1 Editors' Footnote: A corresponding account by an anthropologist has been commissioned for publication in the next issue of the JBA. Barbara Czarniawska will be given the opportunity to comment on this account and, thereby, to open up a debate. 
hospitals, cities, and virtual worlds. Will it be yet another research fashion? Or will this relationship become stabilized, permitting organization studies to fulfil its old but forever thwarted ambition: to show how organizing happens? The beginnings, as illustrated in the following section, were not promising; the ending is much more so.

\section{The times that were: a tale of three dissertations}

My personal encounter with anthropology dates back to my stay as a Visiting ACLS Fellow at MIT during the academic year 1981/1982. Doctoral students at the time learned regression analysis - and field methods from John Van Maanen. My mentor, Lotte Bailyn, advised me to read Rosalie Wax's Doing Fieldwork: Warning and Advice (1971/1986). I finished reading it at three o'clock in the morning, marvelling that a scientific book could keep me as fascinated as a detective story. I became curious about the issue of fieldwork in organization studies, and was shown the original of Henry Mintzberg's doctoral thesis from 1968: "The manager at work - determining his activities, roles and programs by structured observation". His advisor was Edward H. (Ned) Bowman, professor of operations management.

I could recognize in it his study of the work of five chief executives, reported in The Nature of Managerial Work (1973), but the book was quite different from the thesis: broader in scope, but also ... more structured. The original thesis was much closer to ethnography, although the study method was far from traditional anthropological observation. Mintzberg's starting point was not anthropology, but his disappointment with earlier diary studies of work:

Not one of these studies provides substantial insight into the actual content of managerial activities. (...) The reader is told where managers spend their time, with whom they spend their time, how they interact (telephone, face-to-face, etc.) and so on. But the reader is never told what is transacted.

(Mintzberg, 1970: 88; italics in the original)

Mintzberg suggested another method:

I use the label "structured observation" to refer to a methodology which couples the flexibility of open-ended observation with the discipline of seeking certain types of structured data. The researcher observes the manager as he [Mintzberg shadowed five men] performs his work. Each observed event (a verbal contact or a piece of incoming or outgoing mail) is categorized by the researcher in a number of ways (e.g., duration, participants, purpose) as in the diary method but with one vital difference. The categories are developed as the 
observation takes place.

(1970: 90, italics in the original)

Readers in the 2000s may wonder about this seeming obsession with structure and categories, but at the time Mintzberg wrote these words even direct observation was supposed to be strictly structured. The form for recording observed interaction created by US social psychologist Robert Bales (1950) was being widely used. Indeed, in the same journal article, Mintzberg apologized to the reader who "may feel that some of the categories are not sufficiently 'neat'" (p. 94).

Between listing the categories, Mintzberg gave examples of his field notes, revealing that he had, in fact, shadowed "Mr. M". He had sat in M's office and walked with M to the plant; they had returned to the office and then gone to a meeting with consultants (in some later descriptions of his work, the term "tracked" has been used, but it was later appropriated by Mintzberg for other purposes; see Mintzberg, 2007).

It took at least twenty years for Mintzberg's methodological approach to be taken for granted in organization studies; it took thirty years before a work of an anthropologist, Harry Wolcott, became a methodological hit in social sciences, including organization studies.

Harry F. Wolcott was an anthropologist who had studied the Kwakiutl for his doctoral dissertation, before turning his attention to the field of education, and it is this later dissertation that is of interest here. Like Henry Mintzberg, he noticed that diary-type studies suffered from many shortcomings, and would not allow him to answer his central question: "What do school principals actually do"? He did not seem to be aware of Mintzberg's study, not only because the two studies were done practically in parallel, but probably also because management was not yet perceived as a general profession in the 1970s; nor was its knowledge base seen as applicable to all domains of life, as it is now. Wolcott decided to put his anthropological skills to work, but realized from the beginning that his study, focusing as it did on one school principal, would differ markedly from studies of tribes or kinship (Wolcott, 1973/2003).

In a letter to Jay Gubrium, Wolcott explained how his approach acquired the name "shadowing":

If the idea of "shadow studies" developed as a consequence of the publication of Man in the Principal's Office: An Ethnography (HRW 1973), it evolved in a rather indirect and unintentional way. I was well-enough aware that I was already stretching the boundaries of ethnography with a study of an elementary school principal across town. The whole idea of doing ethnography locally, and in school, of all places, seemed new and novel. So novel that the first chapter of the book dealt with how I went about the study. One of the 
nicknames I acquired during those two years (1966-1968)

was The Shadow, based on the radio show of years ago, and as I report in the sixth paragraph of the book (1973: 2 ), that was a nickname that stuck. It also provided a successful explanation of my role, an observer who might turn up anywhere that the principal himself turned up. What The Shadow did was shadowing, and in explaining my research approach, that is a term that I used casually (e.g. p. 3). Personally I found something sinister in the idea that I was "shadowing" someone else, acting like a detective, but I think others used the expression more light-heartedly, and it lent itself to a good-natured banter.

(Wolcott, 2000: reprinted with permission in Czarniawska, 2007)

Although Wolcott's shadowing consisted primarily of unstructured observation, the spirit of the times left its trace, in that he undertook structured observation as well, noting the activities and interactions of the principal at 60-second intervals for two hours at a time.

Thus in the 1970s, Henry Mintzberg had to hide his anthropologyinspired approach under a "structural" disguise; Harry Wolcott did not have to hide his approach, but then his study was not perceived as an "organization study". This spirit of the times was fading away when I visited MIT in 1981, and it had apparently vanished by 1987, when Gideon Kunda defended his doctoral thesis there. His advisers were anthropologist John Van Maanen and Edgar Schein, a social psychologist who had been strongly influenced by anthropology. Kunda studied an intentional attempt to construct an "organizational culture" in a high-tech company (thus the ironic title Engineering Culture). His approach was anthropological through and through; an Israeli citizen, he felt like he was studying an exotic culture. He went to Tech (a pseudonym) three to five days a week for six months to observe the activities of a group of staff members at corporate headquarters. He spent another six months observing a group of line workers, while continuing to maintain contact with the staff people. He interviewed and held informal conversations; frequented all types of pubic activities; and joined all the open events, like workshops and sports. In contrast to many later ethnographies, professional work was not his focus; as he was studying the "construction of culture", he observed managerial activities and their results.

When the thesis was published as a book in 1992, its ethnographic character was emphasized rather than hidden:

This study belongs to the genre known as "ethnographic realism." This identification says much about presentational style, little about the actual research process. The descriptive style of this genre presents an author functioning more or less as a fly on the wall in the course of his sojourn in the field - an objective, unseen 
observer following well defined procedures for data collection and verification. It requires no great insights, however, to recognize that ethnographic realism is a distortion of convenience. Fieldwork, as all who engaged in it will testify, is an intensely personal and subjective process, and there are probably at last as many "methods" as there are fieldworkers.

(Kunda, 1992: 229)

And so on and so forth, in a similar tone. The book has become a bestseller and has been recently (2006) reissued in the second edition. Something pivotal had happened, and as its observer and participant, I tried to capture it on my own work.

\section{A move toward an anthropology of complex organizations: the 1990s}

In 1989, I edited a special issue of International Studies of Management \& Organization (ISMO 19/3), which I prefaced with an excerpt from a book manuscript I had been working on at that time, called Anthropology of Complex Organizations. Sage published the book in 1992, changing its title to Exploring Complex Organizations: A Cultural Perspective. My publisher explained to me that because I was (and am) not an anthropologist, I should not use the word "anthropology" in the title; and furthermore, it would be placed on the wrong shelf in bookstores (those were the days when books were sold in bookstores, and not on the Web).

My reasoning, in the special issue, as in the book, went as follows. Large and complex organizations are among the most characteristic signs of our times. Yet there are few traditional methods that would allow the study of this phenomenon, so central to contemporary cultures. Neither macroeconomics, with this bird's eye perspective, nor the theory of the firm, which reduces organization to a Super-Person, a "decision-maker", has much to offer. Social psychology requires groups; it is not certain that group behaviour covers everything that occurs in complex organizations. If the phenomenon of a large and complex organization is seen as a central tenet of contemporary cultures, however, then anthropology is a discipline to turn to for help. And turn I did.

\section{The definition of organization}

The definition of organization I presented in ISMO differed slightly from that in the book. The earlier one went as follows:

Organization is a system of collective action, undertaken in the effort to influence the world (...) The contents of the action are meanings and things (artefacts). One system of collective action is distinguishable from another by the kind of meanings and products socially attributed to a 
given organization.

(Czarniawska, 1989: 3)

In the book, the word "system" was replaced by the word "net": "organizations are nets of collective action..." (1992: 32). When analysing the reasons for which organization theory had earlier parted ways with anthropology. ${ }^{2}$ I concluded that it was systems theory, among other things, that contributed to the rift. After all, anthropologists had always studied "the organization", but they did not mean entities separated by boundaries from the "environment". Even Eric Trist, trained as an anthropologist, found the traditional methods wanting and opted for the systemic approach. Participant observation, yes; action research, yes; but not traditional anthropological analysis (Fox, 1990). Indeed, for at least 20 years, cybernetics and systems theory held practically all social scientists in thrall (including anthropologists; see Bateson, 1979), so that "system" crept into my text almost automatically, and only a keen anthropologist reviewer pointed it out to me. In my opinion, however, and in the opinion of many of my colleagues, the time was ripe for another encounter. ${ }^{3}$

\section{Anthropology evoked}

I had chosen Edmund Leach (1982) as my main guide to anthropology, because I liked his definition of the field as "a study of the unity of humankind through a study of its diversity". Each study of humankind has as its basis the difference between humans and non-humans, I reasoned. As complex organizations undoubtedly contain both, studying these differences and the ways of cooperation between the two would be useful. Thus I was trying to introduce the studies of science and technology through the back door. Leach was a social anthropologist, and his study objects were doubly human: as "anthropos" and as "social".

It was only when my manuscript was almost ready that I learned from US anthropologist Constance Perin 4 about the revolution within anthropology over things that were said and written by Clifford and Marcus (1986), Marcus and Fischer (1986) and Rosaldo (1989), for example. But even today I can see what I liked about Leach's approach. He suggested that anthropological studies should be historical, but not historicist: firmly situated in time and space, but without any kind of determinism in analysis. Leaning more toward ethnology than toward

\footnotetext{
2 According to Dwight Waldo (1961: 217-8, fn. 7) when organization theory was still called administration theory, "some of the students of organization are more anthropological than anthropologists".

3 In the 1980s, scholars interested in symbolism formed a network called Standing Conference on Organizational Symbolism (http://www.scos.org/)

${ }^{4}$ http://constanceperin.net/
} 
anthropology, he suggested studying the way of life of selected people (which I then remade into "way of work"), and, in a Goffmanian style, to see it as enactment of a social drama. And then he made the most enchanting admission:

Social anthropologists are bad novelists rather than bad scientists. But I hold that the insights of the social anthropologist have a special quality because of the arena in which he [sic] characteristically exercises his artistic imagination. That arena is the living space of some quite small community of people who live together in circumstances where most of their day-to-day communications depend upon face-to-face interaction. This does not embrace the whole of human social life, still less does it embrace the whole of human history. But all human beings spend a great deal of their lives in contexts of this kind.

(Leach, 1982: 53-54)

This admission apologetically assumes a narrative approach, and a conviction that life takes place "locally". But Leach's take neglects the connectedness between localities (see e.g. Sassen, 2001), and his statement was formulated long before more and more people started to spend a good part of their lives in a form of "response presence" (Knorr Cetina and Bruegger, 2000) - in front of their computers.

My other anthropological references survived the passage of time better, however. Geertz's The Interpretation of Cultures (1973) became fashionable in the early 1990s, but it is significant that Geertz listened to the young revolutionaries and, although keeping a somewhat ironic distance, contributed much to the wave of reflexivity in anthropology (see e.g. Geertz, 1988).

I have also included Mary Douglas' book How Institutions Think (1986) because Constance Perin took me along when she went to listen to Douglas lecturing at Uppsala University. The idea that classifications are at least as important in modern societies as they were in "primitive" societies (Durkheim and Mauss, 1903/1963) circulates impressively, not the least through such works as Bowker and Star (1999) and Bowker (2006).

I have also included Castaneda (1968/1986), still fashionable at that time, and Thomas P. Rohlen (1974), whose work is a standard example of an anthropologist studying an exotic (Japanese) company. Yet another example was Latour and Woolgar's Laboratory Life (1979/1986), as Latour was still presenting himself as an anthropologist in the late 1970 s. 
Having listed classical examples of organization studies that were close to ethnographies (Dalton, 1959; Crozier, 1964; Kanter, 1977), I turned to other fields and other authors, whether or not they declared themselves "organization scholars". An excursion into ethnomethodology revealed Bittner (1965), whose advice on how to study organizations is still valid, and Silverman and Jones's (1976) study of organizational careers. A similar excursion into political anthropology threw light on the work of Abner Cohen (1974, 1981), Michael Burawoy (1979), and Tony Spybey (1989). Finally, I concentrated on the growing branch of organization studies: organizational culture.

There, I started with historical antecedents - Elliot Jaques' The Changing Culture of a Factory (1951) and Barry A. Turner's Exploring the Industrial Subculture (1971) -before moving to more recent developments. Among them were Deal and Kennedy's Corporate Cultures (1982), Edgar Schein's Organizational Culture and Leadership (1985), and Frost et al.'s Organizational Culture (1985). The latter had another edition in 1991, which by then was entitled Reframing Organizational Culture. Already, the subdivisions seem to be clear enough (see e.g. Smircich, 1983): "corporate culture" as a managerial tool, a conceptualization favoured by consultants; "organizational culture" as a metaphor for organization, where the organization is seen as a village or a tribe, or a site of organizational symbolism. Thus the 1990s saw "organizational culture" in all its variations as a full-fledged member of organization studies. Organization studies embraced anthropology, and the encounter had a dynamic character.

\section{What happened in time}

Leach, "at the risk of being old-fashioned" (1985), was against anthropologists studying their own cultures:

[F]ieldwork in a cultural context of which you already have intimate first-hand experience seems to be much more difficult than fieldwork which is approached from the naive viewpoint of a total stranger. When anthropologists study facets of their own society their vision seems to become distorted by prejudices which derive from private rather than public experience.

(Leach, 1982: 124)

Leach saw himself as old-fashioned because, by 1980, Britan and Cohen (quoted also by Heyman) had already claimed that anthropology had to move into modern societies, as more and more societies are modern:

Today, the context of human social life has changed drastically. As local communities have become incorporated into large systems, lineages, clans, age-sets, chiefs and big men have all declined in importance. 
Simultaneously, classes, ethnic group, and formal organizations have emerged with increasing significance throughout the world.

(Britan and Cohen, 1980: 9)

Organizations in foreign contexts became more and more closely connected to local contexts, aid organizations being a good example (David Mosse, 2004/2007). Furthermore, certain organizations within a local context - hospitals, for example - can be more exotic than organizations in a foreign context previously studied. What is more, projecting an alien perspective - that of organization theory, for example - onto a well-known phenomenon like the university (Marilyn Strathern, 2000/2007) could produce the desired estrangement. Sharon Macdonald (1995/2007) announced a rapprochement not only with science studies, but also with marketing and consumer studies, soon to be developed even more.

Thus there is continuity, but also change. There are things and topics that are new, but with clear connections to the past.

\section{The times we live now: the triumph of ethnography}

By the 2000s, certain developments were clearly visible. "Corporate cultures" became the domain of consultants. Organizational symbolism was absorbed by two separate trends. One was the narrative turn, which also reached organization theory, itself split into two parts: one inspired primarily by narratology (e.g. Czarniawska, 2004b) and one close to folklore studies ("storytelling", see e.g. Gabriel, 2000). The other was cultural studies - sociology inspired by anthropology - which focused mostly on popular culture (see e.g. Rhodes and Westwood, 2009). One thing is sure, however: ethnography is the dominant method in organization studies at present (see e.g. Nyland, 2007, and Ybema et al., 2009), although the term has acquired a wide variety of meanings.

The influence of anthropology on organization studies further weakened the impact of systems theory. In my chapter reprinted by Jiménez (Czarniawska 2004a/2007), I was already convinced that "organizations" are epiphenomena: they are one of the products of an action net that may spread wider and further than any organization.

On the other hand, this encounter also caused certain criticisms of traditional anthropological methods: "the cardinal rule of ethnography the necessity for a prolonged period of participant observation encounters four problems in research on organizing: of participation, of time, of space, and of invisibility" (Czarniawska, 2004a/2007: 536-7). To counteract these problems, I suggested a "mobile, symmetrical ethnology". Instead of describing it in hypothetical terms, however, I illustrate it in the next section with concrete examples. 
The stories for our times

I have chosen three examples of organization studies by a philosopher, an anthropologist, and a sociologist. This choice is meant to illustrate the growing transdisciplinarity of organization studies. Such studies are no longer "cross-disciplinary" in the sense prevalent in the 1970s, when representatives of different disciplines would agree to study the same object, primarily to discover that "the object" was not the same after all (Czarniawska, 2003). It is researchers who have become transdisciplinary, not research projects.

Further, I have chosen just these three because they practice a symmetrical approach (humans and non-humans, Western and nonWestern cultures treated alike), and because of the novelty of their writing style (Mol, Rottenburg) or the novelty of the field under study (MacKenzie). For these reasons, these three works, especially when contrasted with dissertations described earlier in this text, are good illustrations of the present promises for anthropology-inspired organization studies.

In The Body Multiple: Ontology in Medical Practice (2002), Dutch philosopher Annemarie Mol describes the diagnosis and treatment of atherosclerosis, drawing on her fieldwork in a Dutch university hospital. At first glance, Mol does what many other researchers currently try to do: she depicts a local practice in the health sector, and draws some abstract conclusions from her study. But her book is far from ordinary. She separates her text into two parts on each page. The upper part relates to her ethnography of the diagnosis and treatment of atherosclerosis in the hospital under study. The innovative aspect of her study method is that she followed, or "shadowed" the patient's body, thus being able to show how, moving from one hospital department to another, the body, the patient, and the disease transform into different ontological entities.

The lower part of the page contains a developing theoretical reasoning on various stances in medicine, philosophy, and social sciences. Like the upper part, it is divided into chapters, and each theoretical part is relevant for the ethnography part it underpins. The reader can choose to read the theory first and the ethnography afterwards, or the other way around. One could also say that the ethnography part contains the plot of the story being told, whereas the theory part contains a metaplot; it is, in fact, a theory about changes and developments in theories. Mol's would be a hard act to follow, but it is an example of a most ingenious way of combining theoretical reflection with an attention-getting rendition of the field material.

Two other of Annemarie Mol's innovations are noteworthy. Apart from observation, she also uses "ethnographic interviews", but not in the sense given to the term by US anthropologist James Spradley (1979), who 
coined the expression. For him, the purpose of such interviews was "to describe a culture". In contrast, Mol suggests that the term "ethnographic interviews" should mean that the interviewees themselves become ethnographers (2002: 15). Furthermore, she replaces the well-known concept of "tacit knowledge" with "embedded knowledge" in her analysis - to denote knowledge accumulated in various parts of an action net created by the actions of the producers, their suppliers, and their clients, which is activated by each of them for the purpose at hand without the need for anybody to master the whole of it.

Richard Rottenburg's Far-fetched Facts. A Parable of Development Aid (2009) is a book by an anthropologist, which shows, dispassionately and convincingly, why development projects are doomed to fail in their present form. Based upon first-hand knowledge of such projects, Rottenburg claims that the main problem resides in the differing communication styles of the various actors involved in the project: the Western financiers, the consultants hired to run the project, the local authorities, and the local practitioners. They communicate in different codes, resulting in a veritable Tower of Babel, in which all the participants believe that they are speaking the same language, yet no understanding occurs. When two parties share the code, they are even more prone to neglect the fact that the others do not share it. Technical aids - lists, calculations, tables, computer programs - merely contribute to the confusion rather than rectifying it.

Rottenburg tells the story through several voices, each of which presents its own version of a development project in Ruritania (all names are fictive). The narrators are all acute observers, able to point out the shortcomings of their partners; among them, they represent objectivism, relativism, and constructivism. But these three perspectives cannot merge, and the project is on the verge of collapse.

Following the project over time, Rottenburg arrives at a description of a common pattern that applies not only to development projects, but to projects in general. In the beginning, one leaves as much as possible open; in the end, one concludes as much as necessary for accounting purposes. About midway through the project, plans and contracts must be adapted to developments, so it is possible to conclude what needs to be concluded. Projects routinely suffer from a midlife crisis at this point, because the uncertainty that is desired at the start prevents a simple comparison of the actual state achieved with the contractually agreed-upon target state. It then becomes inevitable that all parameters must be redefined: the given situation, the targeted solution, the contract conditions, and the procedure for assessing the achieved state. This redefinition must be denied, however, or it would give the impression that the project is unpredictable and, consequently, financially incalculable. That would result in the loss of an indispensable prerequisite for conducting future projects. This aporia can be resolved 
by appealing rhetorically to contractual stipulations and facts on the official level, and secretly redefining the entire situation as an unofficial one (Rottenburg, 2009: 167).

In the project in question, one of the parties - the strongest refused to admit the necessary redefinition of the situation, and the weakest party was therefore forced to file for bankruptcy. The error committed by the losing party was to believe too strongly in "facts and figures" as accurate representations of a reality that would finally prevail. Yet written documents were among the villains of the story, because they cannot change when the context and its definition have changed.

Yet the book is not pessimistic in its conclusions, which can be applied to all projects undertaken in the contemporary multicultural world. Rottenburg suggests a pragmatist solution for this type of impasse. By maintaining, consciously and temporarily, an illusion of the Enlightenment - of a language that signifies the actual world and is accessible to all who want to speak it - it is possible to reach an understanding that can be translated into local vocabularies.

Donald MacKenzie's Material Markets: How Economic Agents Are Constructed (2009) is only one among several ethnographies of financial institutions, blooming now in the wake of the creation of a new branch of social sciences: social studies of finance (see e.g. Knorr Cetina and Preda, 2005). I have chosen MacKenzie's work rather than, for example, Karen Ho's Liquidated. The Ethnography of the Wall Street (2009) (discussed by Batteau and Psenka in this issue of the JBA), precisely because MacKenzie is a sociologist of science and technology who uses anthropology for his purposes rather than submitting to the conventional requirements of the genre. This is how he explains the particulars of this approach:

Those who have worked in the social studies of science and technology tend to acquire sensitivities, interests, and intellectual resources that differ at least to a degree from those of the wider disciplines to which we belong (...)

What is perhaps most characteristic of a perspective rooted in the social studies of science and technology is its concern with the materiality of markets: their physicality, corporeality, technicality.

(MacKenzie, 2009: 2)

Thus his approach bridges the gap between the traditional topics of archaeology (material culture) and anthropology (nonmaterial culture), situating both firmly in the modern era. The fieldwork on which the book is based was conducted by the author, but also by other scholars; it uses observation (including participant observation by one of MacKenzie's coauthors) as well as 189 interviews. Thus a reader, who does not know or understand the workings of finance, can actually grasp what people working in finance $d o$, rather than how they think (which is Ho's focus). The results can, hopefully, reach beyond academia, as MacKenzie (2009: 
185) explains:

Markets are of course central to modern life, and are here to stay: a comprehensive move away from market forms of economic provision is close to inconceivable. Yet most people's direct experience of the markets is limited. (...) Financial markets are littered with what the social studies of science and technology tends to call "black boxes" of this kind (...) devices, practices, regulations, organizations, models, and so on, the internal structure of which can be disregarded or which are opaque to outsiders, often because their contents are regarded as "technical" (...) Research that opens the black boxes of finance can thus contribute to public as well as academic life.

\section{Methodological lessons and gains}

Studying black boxes renders especially acute one of the four problems of studying organizing (problems of time, of space, of participation, and of invisibility) - invisibility resulting from virtualization of many practices. It so happens that most social studies of finance use the "halfies" (AbuLughod, 1991) for the purpose of penetrating beyond the opaque service: observers who were themselves finance traders or at least undertook the appropriate schooling (Knorr Cetina and Bruegger, 2000; Beunza and Stark, 2003; MacKenzie and Hardie, 2009; and Ho, 2009). What to do, however, if such an option is not available? To answer this question, I quote my own study - not because it is excellent, like the other three quoted in this section, but because it happens to resolve this problem.

At the beginning of my study of news agencies (Czarniawska, 2012), I was not quite sure how to shadow people who work primarily at and through their computers. In the past, I had frequently shadowed managers who used computers only sporadically (Czarniawska, 2007). True, my colleagues are now developing sets of techniques to be used in creating "virtual ethnographies" (Hine, 2000) - research done on the Internet. Apart from computer studies, which have a different purpose, ways of studying people working with computers are not yet well developed. Yet some forays into this domain can be found in Jemielniak and Kociatkiewicz (2009).

Much to my relief, my hosts at the Italian news agency, ANSA, easily solved my problems. They simply gave me a place at a computer with two screens, such as they were using themselves, and although I could not intervene in their work, I could see "the desk" and "the wire" and shadow the news through the production process. When a discussion started in the newsroom concerning a specific news item, I could trace it in the database, and therefore always (well, almost always) knew what they were talking about. 
Not even my shadowing seemed to be a problem. After all, shadowing consists of watching over people's shoulders as they work and receiving explanations, and, I quickly learned, they were certainly used to that in the newsroom. Thus I could physically follow people in managerial positions when they went to meetings or even to the cafeteria (lots of fascinating conversations took place there); could observe face-to-face interactions in the newsroom; was allowed to look over the shoulders of people performing specific tasks (desk editors); and could follow production on the screen. Anthropological methods require but a slight adjustment in order to fit modernity.

As to "participation", in the case of organization research, participant observation means that the researcher assumes the role of a member of the organization or, alternatively, an employee becomes a researcher. This was the method adopted by Melville Dalton, who worked as a manager; Michael Burawoy, who worked as a machine-tool operator; John Van Maanen, who was a police trainee; and Robin Leidner (1993) who was a McDonald's worker and a Combined Insurance trainee.

These examples indicate that such studies - no doubt superior to all other types - are possible to conduct only with exceptional luck in obtaining access, or because the workplace does not require specific qualifications. I could probably try to act the role of personnel manager, but it would require such an effort that it would effectively prevent me from observing. Participation in a dance differs from participation in an emergency meeting of top management. Although Prasad and Prasad (2002) have claimed that top levels of the hierarchy are hidden from the ethnographic gaze, they overlook the fact that these levels may simply be difficult to access in participative mode.

It is necessary to emphasize at this juncture that I have been using the term "participant observation" literally, excluding situations in which the researcher is present as an observer rather than as a participant, as in the cases of Gideon Kunda (1992) and Mitchel Abolafia (1998). Such nonparticipant observation is an obvious possibility for organization scholars, and it is enhanced if the observation time is prolonged. Still, this is not to say the longer, the better.

The issue of time is especially problematic in organization studies. Consider, for example, the advice that science anthropologist Sharon Traweek has given to her colleagues in her article on fieldwork strategies in science studies:

Our first field work should last a minimum of one year, preferably two; subsequent field trips can last as little as three months as long as they occur at least every three or four years. The questions and theories change, but we study the same people if they survive as a community, and maybe later on we also study some of their neighbours.

(Traweek, 1992: 438) 
My study of the management of the City of Warsaw (Czarniawska, 2002) took me about fourteen months. During that time, a new city council was elected, which meant that I lost half of my interlocutors. Moreover, the "neighbours" also changed as a result of an administrative reform. The point is that I was not studying a community of city managers but an action net of city management: interconnected acts of organizing (Czarniawska, 2004a).

Traweek had studied the Japanese physicists for something like 20 years before she began to feel that she was getting the gist of their lives and activities. Suppose I studied Warsaw management for twenty more years. It would no doubt be a fascinating study, but I am not sure that there will be much in the management of Warsaw in 2015 that was of crucial importance for understanding the management of that city in 1995. There is no "essence" that I could have revealed, given time. Specific persons may retire or become exchanged as the result of the next political coup, but the actions that constitute management will remain. On the other hand, the form and content of the actions may change drastically, even if the same people remain as a result of, say, a new information technology or a new fashion in big city management.

"Japanese physicists" may produce an impression of stability, quite incidentally, by remaining in the same space. But do they, actually? Time and space are inextricably intertwined in practice, although they become separated in theory. This separation facilitates particular theoretical biases. German anthropologist Johannes Fabian (1983) said that traditional anthropology counted the time of the Other in a different way than it counted "our time". I will simplify Fabian's complex argument by mentioning two such differences: the first is that the Other's time goes more slowly than does ours; and the second is that it is not considered coeval (the Other is perceived as living in another era). Now, time in contemporary, complex organizations is condensed, and it is counted at many places concurrently. It is not only coeval, but also multiple. And it runs fast. The journalists I studied could not understand why I needed so much time to write my report. They believed as well that it would become obsolete in a year (Czarniawska, 2012).

Hanns-Georg Brose (2004) developed this line of thought in a helpful way. He suggested that contemporary western societies are characterized by three connected phenomena. The first is acceleration, the speeding up of social processes, shorter life-cycle of products, higher pace of innovation, accompanied by such acts of resistance as the slow food movement. According to Brose, acceleration and the resistance to acceleration must be studied together. The second phenomenon, related to the first and commented upon frequently by Zygmunt Bauman (e.g. 1995), is the shortened time horizon of expectations and orientations, resulting in a shorter duration of social structures and personal commitments. Both are causes and effects of the third phenomenon: an 
increasing simultaneity of events, in what Schütz and Luckmann (1983) called "the world at reach". In this context, Brose formulated a question that is very apt as a rationale for this text, especially if the "we" in his utterance is understood as "we social scientists":

More and more rapidly varying events seem to appear on our different screens, overlapping and blurring the rhythms of our everyday life (e.g. work and leisure) and life-courses, breaking the gendered coupling of work and education. As the functioning of the ordering principles (first things first) and synchronizing mechanisms (calendars and clocks) cannot be taken for granted any more, are we deemed - like with television - to zap around?

(Brose, 2004: 7)

As our world at reach has widened, there is a problem in trying to record and interpret it. Zapping is one solution; a bird's-eye view another; but they hardly solve the difficulty of contemporary fieldwork: how to study the same object in different places at the same time? Here another difficulty resulting from an attempt to follow the anthropological tradition is revealed: dealing with space. An observer is usually situated in one room, one corridor, or one branch, although some excursions may occur, especially when a shadowing technique is used. Modern organizing, on the other hand, takes place in a net of fragmented, multiple contexts, through multitudes of kaleidoscopic movements. Organizing happens in many places at once, and organizers move around quickly and frequently. As Lars Strannegård aptly noted in the title of his fascinating study of an IT company (complemented by the artwork of Maria Friberg), the people he studied were constantly "already elsewhere" (Strannegård and Friberg, 2001). Additionally, not all interactions require a physical presence. Knorr Cetina and Bruegger (2000) have spoken about embodied presence and response presence, the latter not necessarily visible to an observer, as when people "talk" to somebody via e-mail. As Barley and Kunda (2001:85) have pointed out, traditional observation is usually inadequate to capture any type of computer work, so they recommend a more sophisticated use of technical aids in observation.

Brose (2004) concluded that the increasing simultaneity also causes an increase in non-simultaneity of the number of people who, while living at the same time, do not live in the same time. The phenomenon seen by Fabian as produced by anthropologists becomes global, as the distinction between the modern and the non-modern collapses. Therefore Brose postulates, and I cannot help but agree with him, that there is a need to study the emergence of new practices and structures that are supposed to show a way to live and work with different temporalities; a way that no longer relies on a hierarchical or sequential ordering of activities. 
The present triumph of ethnography in organization studies can be explained by scientific fashion (strengthened by the non-scientific uses of ethnography, see e.g. Greenwood, 2008), but also by a general enthusiasm for opening black boxes. Additionally, at least three decades after it was postulated (Weick, 1969/1979), the processual approach seems to be finally winning over the structural one, although not in the sense that this term is used in literature theory. Now that anthropologists have returned from exotic countries and organization theorists have acquired greater experience in wielding anthropological tools, perhaps the time is ripe for a fruitful exchange. Together, we can figure out the best ways of studying what people in contemporary societies do when they organize.

\section{References}

Abolafia, Mitchell Y. 1998 'Markets as cultures: An ethnographic approach.' In Michel Callon (ed.) The laws of the markets. Oxford: Blackwell, 69-85.

Abu-Lughod, Lila 1991 'Writing against culture.' In W: Fox, Richard G. (ed.) Recapturing anthropology. Working in the present. Santa Fe, New Mexico: School of American Research Press, 137-62

Bales, Robert F. 1950 Interaction process analysis. Cambridge, MA:

Addison-Wesley.

Barley, Stephen R. and Kunda, Gideon 2001 'Bringing work back in.' Organization Science, 12(1): 76-95.

Bateson, Gregory 1979 Mind and nature: A necessary unity (Advances in systems theory, complexity, and the human sciences). Creskill, NJ: Hampton Press.

Bauman, Zygmunt 1995 Life in fragments: essays in postmodern morality. Oxford: Blackwell.

Beunza, Daniel and Stark, David 2005 'How to recognize opportunities:

Heterarchical search in a trading room.' In: Knorr Cetina, Karin and Preda, Alex (eds.) The sociology of financial markets. Oxford, UK: Oxford University Press, 84-101.

Bittner, Egon 1965 'The concept of organization.' Social Research, 31: 240255.

Bowker, Geoffrey C. 2006 Memory practices in the sciences. Harvard, MA: The MIT Press.

----- and Star, Susan Lee 1999 Sorting things out. Harvard, MA: The MIT Press.

Britan, Gerald M. and Cohen, Ronald 1980 'Toward an anthropology of formal organizations.' In: Britan, Gerald M. and Cohen, Ronald (eds.) 
Hierarchy and society: Anthropological perspectives on bureaucracy. Philadelphia, PA : Institute for the Study of Human Issues, 9-30.

Brose, Hanns-Georg 2004 'Introduction. Towards a culture of nonsimultaneity?' Time \& Society, 13(1): 5-26.

Burawoy, Michael 1979 Manufacturing consent. Chicago, IL: University of Chicago Press.

-----, Burton, Alice, Ferguson, Ann Arnett, Fox, Kahryn J., Gamson, Joshua, Gartrell, Nadine, Hurst, Leslie, Kurzman, Charles, Salzinger, Leslie, Schiffman, Josepha and Ui, Shori 1991 Ethnography unbound. Power and resistance in the modern metropolis. Berkeley, CA: University of California Press.

Castaneda, Carlos 1968/1986 The teachings of Don Juan. Berkeley, CA: University of California Press.

Clifford, James, and Marcus, George E. (eds.) 1986 Writing culture: The poetics and the politics of ethnography. Berkeley, CA: University of California Press.

Cohen, Abner 1974 Two-dimensional man: An essay on anthropology of power and symbolism in complex society. Berkeley, CA: University of California Press.

---- 1981 The politics of elite culture. Berkeley, CA: University of California Press.

Crozier, Michel 1964 The bureaucratic phenomenon. Chicago, IL: University of Chicago Press.

Czarniawska-Joerges, Barbara 1992 'Exploring complex organizations: A cultural perspective.' Newbury Park, CA: Sage.

---- 2002 A tale of three cities, or the glocalization of city management. Oxford University Press.

----- 2003 'This way to paradise: On creole researchers, hybrid disciplines and pidgin writing.' Organization, 10(3): 430-434.

----- 2004a 'On time, space and action nets.' Organization, 11(6): 777-795.

----- 2004b Narratives in social science research. London: Sage.

---- 2007a Shadowing and other techniques for doing fieldwork in modern societies. Malmö: Liber.

---- 2012 Cyberfactories. How news agencies produce news. Cheltenham: Edward Elgar.

Dalton, Melville 1959 Men who manage. New York: Wiley.

Deal, Terrence E., and Kennedy, Allan A. 1982 Corporate cultures: The rites and rituals of corporate life. Reading, MA: Addison-Wesley.

de Certeau, Michel 1984 The practice of everyday life. Berkeley: University 
of California Press.

Douglas, Mary 1986 How institutions think. London: Routledge and Kegan Paul.

Durkheim, Émile and Mauss, Marcel 1903/1963 Primitive classifications. London: Cohen and West.

Fabian, Johannes 1983 Time and the Other. How anthropology makes its object. New York: Columbia University Press.

Fox, William M. 1990 'An interview with Eric Trist, father of the sociotechnical systems approach.' Journal of Applied Behavioral Science, 26(2): 259-279.

Frost, Peter J., Moore, Larry F., Louis, Meryl R., Lundberg, Craig C. and Martin Joanne, (eds.) 1985 Organizational culture. Beverly Hills, CA: Sage.

-----, Moore, Larry F., Louis, Meryl R., Lundberg, Craig C. and Martin Joanne, (eds.) 1991 Reframing organizational culture. Beverly Hills, CA: Sage.

Gabriel, Yiannis 2000 Storytelling organizations. Oxford University Press. Geertz, Clifford 1973 The interpretation of cultures. New York: Basic Books.

---- 1988 Works and lives: The anthropologist as author. Stanford University Press.

Greenman, Andrew 2008 Brand new talk: Constructing fashionability in a consulting trend. International Studies of Management \& Organization, 38(2): 44-70.

Hine, Christine 2000 Virtual ethnography. London: Sage.

Ho, Karen 2009 Liquidated. An ethnography of Wall Street. Durham, NC: Duke University Press.

Jaques, Elliott 1951 The changing culture of a factory. London: Tavistock. Jemielniak, Dariusz and Kociatkiewicz, Jerzy (eds.) 2009 Management practices in high-tech environments. IGI Global: Premier Reference Source. Jiménez, Alberto Corsín (ed.) 2007 The anthropology of organisations. Aldershot: Ashgate.

Kanter, Rosabeth Moss 1977 Men and women of the corporation. New York: Basic Books.

Knorr Cetina, Karin and Bruegger, Urs 2000 'The market as an object of attachment: Exploring postsocial relations in financial markets.'

Canadian Journal of Sociology 25(2): 141-168.

----- and Preda, Alex (eds.) 2005 The sociology of financial markets. Oxford University Press.

Kunda, Gideon 1992/2006 Engineering culture. Control and commitment 
in a high-tech corporation. Philadelphia, PA: Temple University Press. Latour, Bruno, and Steve Woolgar 1979/1986 Laboratory life: The construction of scientific facts. Princeton, NJ: Princeton University Press. Leach, Edmund 1982 Social anthropology. Oxford University Press. ---- 1985 'Observers who are the part of the system.' The Times Higher Education Supplement, November 29.

Leidner, Robin 1993 Fast food, fast talk. Service work and the routinization of everyday life. Berkeley: University of California Press.

Macdonald, Sharon 1995/2007 'Consuming science: Public knowledge and the dispersed politics of reception among museum visitors. In: Jiménez, Alberto Corsín (ed.) The anthropology of organisations. Aldershot: Ashgate, 409-425.

MacKenzie, Donald 2009 Material markets. How economic agents are constructed. Oxford University Press.

----- and Hardie, Iain 2009 'Assembling an economic actor.' In: MacKenzie, Donald Material markets. How economic agents are constructed. Oxford University Press, 37-62.

Marcus, George E. and Fischer, Michael M. 1986 Anthropology as cultural critique. An experimental moment in the human sciences. The University of Chicago Press.

Mintzberg, Henry 1970 'Structured observation as a method to study managerial work.' The Journal of Management Studies, February: 87-104.

----- 1973 The nature of managerial work. Englewood Cliffs, NJ: Prentice Hall.

---- 2007 Tracking strategies: Towards a general theory. Oxford University Press.

Mol, Annemarie 2002 The body multiple: Ontology in medical practice. London: Duke University Press.

Mosse, David 2004/2007 'Is good policy unimplementable? Reflections on the ethnography of aid policy and practice.' In: Jiménez, Alberto Corsín (ed.) The anthropology of organisations. Aldershot: Ashgate, 451-483.

Nyland, Daniel 2007 Organizational ethnography. London: Sage.

Prasad, Pushkala; and Prasad, Anshu 2002 'Casting the native subject: ethnographic practice and the (re)production of difference.' In: Czarniawska, Barbara; and Höpfl, Heather (eds.) Casting the other: The production and maintencance of inequalities in work organizations. London: Routledge, 185-204.

Rhodes, Carl and Westwood, Robert 2009 Critical representations of work and organization in popular culture. London: Routledge.

Rice, Albert Kenneth 1958/1987 Productivity and social organization: The 
Ahmedabad experiment. London: Tavistock.

Rohlen, Thomas 1974 For harmony and strength: Japanese white-collar organization in anthropological perspective. Berkeley, CA: University of California Press.

Rosaldo, Renato 1989 Culture and truth. The remaking of social analysis. Boston: Beacon Press.

Rottenburg, Richard 2009 Far-fetched facts. Cambridge, MA: The MIT Press.

Sassen, Saskia 2001 The global city. New York, London, Tokyo. Princeton University Press.

Schein, Edgar H. 1985 Organizational culture and leadership. New York: Jossey-Bass

Schütz, Alfred, and Luckmann, Thomas 1983 The structures of the lifeworld. Evanston, IL: Northestern University Press.

Silverman, David and Jones, Jill 1976 Organizational work. London: Collier Macmillan.

Smircich, Linda 1983 'Concepts of culture and organizational analysis.' Administrative Science Quarterly, 28(3): 339-358.

Spradley, James P. 1979 The ethnographic interview. New York: Holt, Rinehart and Winston.

Spybey, Tony 1989 'Frames of meaning as a concept of organization.' International Studies of Management \& Organization, 19 (3): 16-33.

Strannegård, Lars and Friberg, Maria 2001 Already elsewhere - Play, identity and speed in the business world. Stockholm: Raster.

Strathern, Marilyn 2000/2007 'The tyranny of transparency.' In: Jiménez, Alberto Corsín (ed.) The anthropology of organisations. Aldershot: Ashgate, 485-497.

Traweek, Sharon 1992 'Border crossings: Narrative strategies in science studies and among physicists in Tsukuba Science City, Japan.' In: Andrew Pickering, (ed.) Science as practice and culture. University of Chicago Press, 429-466.

Turner, Barry A. 1971 Exploring the industrial subculture. London: Macmillan.

Waldo, Dwight 1961 'Organization theory: An elephantine problem.' Public Administration Review, 21: 210-225.

Weick, Karl 1969/1979 The social psychology of organizing. Reading, MA: Addison-Wesley.

Wolcott, Harry F. 1973/2003 The man in the principal's office. An ethnography. Walnut Creek, CA: Altamira Press. 
Ybema, Sierk; Yanow, Dvora; Wels, Harry, and Kamsteeg, Frans (eds.) 2009 Organizational ethnography: Studying the complexity of everyday life. London: Sage.

Barbara Czarniawska is a Professor of Management Studies at the University of Gothenburg, Sweden. She studies connections between popular culture and practice of management, and techniques of managing overflow in affluent societies; exploring techniques of fieldwork and the applications of narratology in social sciences. Most recent book in English: Cyberfactories: How News Agencies Produce News (2011). Barbara may be reached at Barbara.Czarniawska@gri.gu.se 